\title{
Going missing: islands, incarceration and disappearance
}

\section{Rationale}

Wholesale disappearances are disconcerting; to victims, those left behind, and perhaps even to perpetrators. The still open-ended account of Malaysia Airlines Flight MH370 from Kuala Lumpur to Beijing on March 8, 2014 offers insights to political geographers. The saga of that flight - still 'missing' at the time of writing (29 December 2014) - shatters the absolutist discourse of state power, and ridicules the regular 'scientific' updates that had become daily news items immediately following the plane's 'disappearance'. Those news briefs initially exuded confidence and hubris by a brandishing of sophisticated tools and methodologies implemented via multi-national cooperation, the display of tracking maps, the submission of 'new 'intelligence', and the reception of hopeful signals and pings. But this gave way to dejection and a growing realization of powerlessness, in turn followed by a tellingly disconcerting silence. The 239 passengers and crew remain caught in that limbo between life and death that cheats closure.

Conspiracy theories about what may have happened to MH370 abound; some stick around and gain credibility because they resonate with deep and longstanding tropes. Hence the staying power of the suggestion that MH370 may have been re-routed to land on the US military base of Diego Garcia, Chagos archipelago, British Indian Ocean Territory (Stieber, 2014).

This suggestion aligns with a history of islands as places where persons, but also states, get erased and rendered absent. Forms of 'disappearance' exude the initiatives of states to rid themselves of certain persons from certain places; and/or to corral certain persons in certain places. One manoeuvre typically begets and supports the other. Here, offshore islands feature prominently as choice enclaves. Think Alcatraz, Changuu, Devil's Island, Gorgona, Robben and Rottnest: islands have served as prison sites, or wholesale prisons, for centuries: still offering a combination of high security with spaces that are out of sight (and hopefully out of mind?) from nosey journalists, pesky human rights activists, or curious members of the public. That prototypical limbo or 'black site', Camp XRay at Guantánamo Bay (on the island of Cuba, but not subject to the judicial purview of its state), leads the way in such offshoring practices (Kaplan, 2005). Wholesale episodes of erasure (as with MH370) also involve smart legalistic manoeuvres that can flout human rights concerns but which can be justified in the name of border control, national security and even environmental conservation: One of Gordon Brown's last decisions as UK Prime Minister in 
2010 was to declare the Chagos archipelago a marine protected area. This is good news to its marine life; while the resettlement of indigenous Chagossians, forcibly exiled, is rendered less likely (Sidaway, 2010).

Echoing Gillis (2014), boundaries (natural, always fluid, rich and dynamic) are different from borders (political, tense and sterile; but also porous, in spite of being presented and intended otherwise). Island regimes continue to offer dynamic examples of how their self-defining geo-physicality suggests border properties, but is a stage for boundary properties. The nature of an island morphs into shady and fuzzy layers of stricture. Not to be outdone, regimes seek to deploy these layers onto the border agenda. Specific groups of 'undesirables' detainees, terrorists, irregular migrants - can be physically rounded up while enjoying mobilities that transcend those denied by, or available through, conventional carceration. Various island jurisdictions are now, willy-nilly, members of an "enforcement archipelago" (Mountz, 2011), embodying examples of how people are managed via their im/mobility on island spaces, with or without necessarily being locked in a prison cell. 'Disappearances' take the form of transfers offshore, to and from spaces where incarceration is a complex discursive engagement between physical prison regimes, island geo-physical separation and jurisdictional territoriality, and the shifts and passages across time that occur within and betwixt these parameters.

\section{A case in point: Pitcairn}

Consider the case of the six men - the rump of able-bodied adult males on the Pacific island of Pitcairn - found guilty in 2004 in the child sex abuse scandal that unfolded in that isolated, 45-strong community. These have been served their sentences; three were locked up in a prison which they first had to build themselves, and whose parts had been transported, in kit form, from Britain (McKie, 2006). But, even while locked in, these men had to be temporarily released to help with oaring the long-boat that is the only life-line between that community and any visiting vessels (The Independent, 2008). Moreover, since 2009, the jail has been empty, and the accused have been serving 'home detention' (The Telegraph, 2008). The fence surrounding the prison has been cut in various places; "chickens and children squeeze through the gap in the gate and gather the fruit that is wasting on the tress within the confines" (Pitcairn Island Prison, 2012). The insiders are out; and the outsiders are in, at least for part of the time.

\section{Why it matters}


Island geography and jurisdiction combine to extend the suite of services that can be competitively provided by small jurisdictions. Among these, differential access to territory, including banning and enforced exile, is a manifestation of power and a privileging of discourses about securitization. The resulting $\mathrm{im} /$ mobilities are more easily enforceable via the island condition, which conceptually takes on the guise/trope of a carceral environment to those left either inside or outside.

The dynamism that accompanies carceration regimes is complicit with the power to include or exclude. It involves the ability to impose, or contest, various levels of imprisonment; just as those found guilty in the criminal justice system may be subjected to what could range from suspended sentences and parole, to transfers to higher security installations and bouts of solitary confinement. It can get worse, with the length of one's detention remaining unknown and at one's jailors' whims or discretion. There is a shifting in and out, with adjusted and changing levels of intensity, clarity and certainty, and with the mobility and fluidity that fulfilling these adjustments and changes imply.

Power in society is often manifest by the ability to move or move faster; the ability to impose or impede the movement of others; and the ability to keep one unsure of what movement, if any, will follow, and when. Those with less power are cheated of options for clarity, mobility or speed. Elites throughout history have tended to be more kinetic. These traits are contemporary responses to Teresia Teiawa's otherwise coy question: "shall we make 'island' a verb?" In so doing, we can sense, and deliver perspectives on, islands as "weaves of existence" (Hägerstrand, 2009), as ongoing and commonly contested processes of creation, with largely indeterminate futures. There are many ways to island, each geographical twist and turn raising complex questions of its own (Baldacchino, \& Clark, 2013, p. 130). Islands are storied 'taskscapes' of multi-level activity and relationships, unfolding and unravelling (Ingold, 2000). For all their enticing selfevident geographies, islands 'become', arising out of the activities, tropes and functions thrust upon them. Islandness, in this vein, weaves in and out, gets produced, alluded to, appealed to, dismissed, accentuated or diluted, in a churn of actions.

\section{Vanishing as ultimate act}

Is disappearance, then, the epitome of this dynamism? Elision provides the final stage of islanding. Like a sinking Titanic, islands provide a powerful geographic trope for disappearance, both literally and figuratively. Unlike mainlands, 
islands can and do become absent: violently (as in the throes of volcanic eruptions, like that of Krakatoa in 1883) or gradually (as with contemporary sea level rise and the Carteret islands). Sovereign archipelago atoll states - Tuvalu, Marshall Islands, Kiribati - face comprehensive drowning with even a modest rise in sea level. Islands at risk of such a vanishing act are the target of a morbid tourism that feeds on their imminent demise (Farbotko, 2010; Huffington Post, 2014). Pitcairn itself is facing another kind of disappearance, with a real risk of comprehensive depopulation and loss of local self-determination (Connell, 1991; Amoamo, forthcoming).

A third category of island thus deserves to be added to those already identified by physical geographers - continental and oceanic islands - as well as to the pair suggested by Deleuze (1974, p. 10), based on the two geophysical forms. Islands are not only about "dreaming of pulling away, of being already separate, far from any continent" and "of starting from scratch, recreating, beginning anew" (ibid.). They are also about wholesale evaporation, being lost in the sense of going missing. The many ways to island need to include vanishing, apart from becoming. Indeed, some islands have been undiscovered: Ferdinandea/ Graham Island came and went in the course of just six months in 1831 (The Basement Geographer, 2011); and Sandy Island has only recently been proven not to exist (BBC News, 2012).

Erasure defies the operationalisation of sharp geographic, cultural and political frames. Nonetheless, it is inextricably linked to issues of power (Amoamo, 2013, p. 234). Erasure is largely the act of looking past, and ignoring or rendering an other invisible (Allahar, 2005, p. 125). In mapping, there is one worse fate for an island than being relegated to an inset: it is not to be drawn at all. Ward (1989) has complained about the island-rich Pacific being drawn as the Earth's "empty quarter" in various world maps.

Geo-politics also unfold as acts of erasure. And islands feature prominently in the geographical imagination of politics (Mountz, 2014). In not forgetting flight MH370, we note the many other islanding performances of people, and states, 'going missing'.

\section{References}

Allahar, A. L. (2005). Identity and erasure: finding the elusive Caribbean. Revista Europea de Estudios Latinamericanos y del Caribe, 79, 125-134.

Amoamo, M. (forthcoming) Engaging diasporas for development: A case study of Pitcairn Island, Australian Geographer. 
Amoamo, M. (2013). Empire and erasure: A case study of Pitcairn Island. Island Studies Journal, 8(2), 233-254.

Baldacchino, G., \& Clark, E. (2013). Guest editorial introduction: Islanding cultural geographies. Cultural Geographies, 20(2), 129-134.

BBC News (2012). South Pacific Sandy Island 'proven not to exist'. 22 November. At: http://www.bbc.com/news/world-asia-20442487 Accessed 29.12.2014

Connell, J. (1988). The end ever nigh: Contemporary population change on Pitcairn island. GeoJournal, 16(2), 193-200.

Deleuze, G. (2004). Desert Islands. In G. Deleuze Desert Islands and Other Texts: 1953-1974. M. Taormina translator. Paris, France: Semiotext(e), pp. 9-14.

Farbotko, C. (2010). Wishful sinking: Disappearing islands, climate refugees and cosmopolitan experimentation. Asia Pacific Viewpoint, 51(1), 47-60.

Gillis, J. R. (2014). Not continents in miniature: Islands as ecotones. Island Studies Journal, 9(1), 155-166.

Hägerstrand, T. (2009). Tillvaroväven [The weave of existence]. K. Ellegård and U. Svedin, eds. Stockholm: Forskningsrådet Formas.

Huffington Post (2014). 10 gorgeous islands you need to visit asap before they disappear. 21 March. At: http://www.huffingtonpost.ca/2014/03/21/disappearingislands-rising-sea-levels n 5006571.html Accessed 29.12.2014.

Ingold, T. (2000). The perception of the environment: Essays on livelihood, dwelling and skill. London: Psychology Press.

Kaplan, A. (2005). Where is Guantánamo? American Quarterly, 57(3), 831-858.

McKie, R. (2006). Rapist relative of Bounty's mutineer enters his DIY jail. The Guardian. November $19 . \quad$ At: http://www.theguardian.com/world/2006/nov/19/robinmckie.theobserver Accessed 29.12.2014

Mountz, A. (2014). Political geography II: Islands and archipelagos. Progress in Human Geography, on-line before print, December 22. Doi: $10.1177 / 0309132514560958$. 
Mountz, A. (2011). The enforcement archipelago: Detention, haunting, and asylum on islands. Political Geography, 30(3), 118-128.

Pitcairn Island Prison. (2012). Pitcairn Island Prison. August 6. At: http://paulandruthontherock.blogspot.ca/2012/08/pitcairn-island-prison2012.html Accessed 29.12.2014

Sidaway, J. D. (2010). 'One island, one team, one mission': Geopolitics, sovereignty, 'race' and rendition. Geopolitics, 15(4), 667-683.

Steiber, Z. (2014). Diego Garcia: missing Malaysia Flight MH370, Philip Wood rumours are 'baseless conspiracy theories' US Says. The Epoch Times. April 15. At: http://www.theepochtimes.com/n3/622238-diego-garcia-missing-malaysia-flightmh370-philip-wood-baseless-conspiracy-theories-us-says/ Accessed 29.12.2014

Teiawa, T. (2007). To island. In G. Baldacchino (Ed.) A world of islands: An island studies reader, p. 514. Charlottetown, PE: Institute of Island Studies.

The Basement Geographer (2011). Ferdinandea: An island that lasted for less than a year. July 4. At: http://basementgeographer.com/ferdinandea-an-islandthat-lasted-for-less-than-a-year/ Accessed 29.12.2014

The Independent (2008). Evil under the sun: The dark side of the Pitcairn Island. July 30. At: http://www.independent.co.uk/news/world/australasia/evil-underthe-sun-the-dark-side-of-the-pitcairn-island-880226.html Accessed 29.12.2014

The Telegraph (UK) (2008). Pitcairn Island sex abuse children to get compensation. 9 October. At: http://www.telegraph.co.uk/news/worldnews/australiaandthepacific/pitcairnisla nds/3166599/Pitcairn-Island-sex-abuse-children-to-get-compensation.html Accessed 29.12.2014

Ward, R. G. (1989). Earth's empty quarter? The Pacific islands in a Pacific century. Geographical Journal, 235-246. 